Valóságos könyvtár - könyvtári valóság. Könyvtár- és információtudományi tanulmányok 2018. Szerk. Kiszl Péter, Csík Tibor.

Budapest, ELTE BTK Könyvtár- és Információtudományi Intézet. 2018. 31-42.

\title{
A (NEMZETI) KÖNYVTÁR ÁLLANDÓSÁGA ÉS VÁLTOZÁSA
}

\author{
KÁLDOS JÁNOS \\ Országos Széchényi Könyvtár - Országos Könyvtári Rendszer Projekt, szakmai vezető
}

\section{TARTALMI ÖSSZEFOGLALÓ}

A digitális kor kezdetén a könyvtár új funkciókkal bővül. Az ezzel kapcsolatos útkeresések a könyvtár négy hagyományos „tartópillére” (gyüjtés, megőrzés, feldolgozás, szolgáltatás) mentén zajlanak.

A technológiai környezet változásával és a komplex hálózatok kialakulásával egyre összetettebbé válik a gyújtési tevékenység határainak kijelölése. A digitalizálás következményeként a könyvtárak belépnek a könyvtárak számára gyújtendő dokumentumokat termelő szervezetek, az előállítók (creator, producer) közé. A könyvtárak digitális gyújteményeinek hosszú távú megőrzésének feladata új technikai megoldásokat követel. Megváltoznak a megőrzés eszközei és a megőrzés felelősségi rendszerei is. A dokumentum-feldolgozás területén tudatosabban kell kezelnünk a könyvtári feldolgozottság különböző szintjeit, szem előtt tartva, hogy a jövőben minden leíró elem növeli a potenciális szemantikai kapcsolódások számát. A könyvtárak egy része adatközponttá válik. A könyvtári szolgáltatási rendszerben jelentős fókuszváltások történtek - a könyvtárak elindultak az olvasók felé.

A fenti gondolatokat különösen időszerűvé teszi a nemzeti könyvtár (OSZK) informatikai infrastruktúrájának és szolgáltatásainak fejlesztésére kapott anyagi támogatás és az időről-időre felmerülő „kettős költözés” gondolata. Ezek a fejlesztések megfelelően reflektálnak arra a sokrétű folyamatra, amelyet a digitális kor jelenségei és elvárásai rónak a könyvtárakra, és lehetővé teszik, hogy az OSZK átlépjen a digitális korszakba.

\section{Bevezetés}

A „Könyvtár”, amiről az alábbi gondolatmenet szól, absztrakció. Az a könyvtár, amelynek példáján vizsgálom és bemutatom a „Könyvtár” állandóságát és változását, az Országos Széchényi Könyvtár. A címben a zárójelbe tett „nemzeti” szó arra utal, hogy a magyar nemzeti könyvtárban, az Országos Széchényi Könyvtárban (OSZK) zajló fejlesztések szorosan kapcsolódnak a Könyvtárban általában végbemenő útkeresésekhez és változásokhoz. A vizsgálatot idôszerűvé teszi, hogy a magyar nemzeti könyvtár jelentős anyagi támogatást kapott arra, hogy megújítsa informatikai infrastruktúráját és szolgáltatásait. ${ }^{1}$ Nagy valószínűséggel néhány éven belül megújul a könyvtár épülete is. ${ }^{2}$ Könyvtárunk fő stratégiai elvei a „kettős költözés” gondolatában összegezhetők, amely egyrészt kifejezi a könyvtárnak mint helynek a megújulását, másrészt a digitális térbe való átköltözést. Úgy véljük, hogy az OSZK fejlesztési tervének összetevői reflektálnak 
KÁLDOS JÁNOS

arra a sokrétú folyamatra, amelyet a digitális kor jelenségei és elvárásai rónak a könyvtárakra. A nagy ívű fejlesztési terv két összetevője megteremti az alapokat ahhoz, hogy az OSZK átlépjen a digitális korszakba.

A könyvtár kettős küldetése a társadalmi emlékezet megőrzése, valamint az öszszegyűjtött és megőrzött adattömeg hozzáférhetővé tételének biztosítása a társadalom adat- és információszükségletei szerint. Lassan negyed évszázada érzékelhető a könyvtárak önértékelésének, társadalmi megítélésének és szerepének változása, átalakulása. A „falak nélküli könyvtár”, a „hálózati könyvtár”, a „könyvtár a felhőben”, a „szolgáltató könyvtár" kifejezések metaforikus képei a könyvtárak állandó és változó szerepeire utalnak. Milyen lesz a digitális kor könyvtára? Miben más, ha egyáltalán más, mint a korábbi korokban? Számtalan konferencia, kutatás, tanulmány, eszmecsere, jövőkép, stratégia és koncepció és/vagy megvalósult épület igyekezett és igyekszik választ adni a fenti kérdésekre. A válaszolók döntő többsége egyetért abban, hogy az új technikai forradalom, amelyben az infokommunikációs technológia, a robotika, a genetika, a nanotechnológia területeinek fejlődése és összekapcsolódása, egymásra hatása és ennek a technikai forradalomnak a társadalomra gyakorolt hatása az alapvető oka annak a paradigmaváltásnak, ami a könyvtárak múködésének jelenlegi és jövőbeli keretét meghatározza.

A Könyvtár a múlt megőrzésének egyik intézményesült központja, a társadalmi emlékezetrendszer része. Legmagasabb szintű feladatai leírhatók a gyűjtés, a megơrzés, a feldolgozás és szolgáltatás, az összegyűjtött tudás disszeminációjának funkcionális modelljével. Ez az „oszloprend” az ókor óta a „könyvtár” négy tartópillére.

\section{Gyüjtés}

A Könyvtár egyik magas szintű funkciója, hogy gyújtse az egy adott közösség által létrehozott, főként írásban rögzített szellemi termékeket a közösség felhatalmazásával és a közösség mindenkori múltbéli tapasztalatának, tudásának megőrzése és továbbadása érdekében. Ez a közösség lehet város, csoport, kutatóközösség vagy akár nemzet. A XXI. században egyre nagyobb közösségek és hálózatok jönnek létre, pl. kulturális-, érték- és/vagy politikai érték-régiók, vagy globális méretű közlekedési-, kereskedelmiés információs hálózatok. A World Wide Web egyike ezeknek a globális hálózatoknak. ${ }^{3}$ Egyre komplexebb hálózati rendszerek alakulnak ki, amelyeket részhálózatok sokasága és azok kapcsolatai alkotnak úgy, hogy a komplexebb hálózat új minőséget teremt. Ez az új komplex rendszer az internet. A hálózatok dinamikusan változnak, folyamatosan mozgásban vannak. Ez a dinamika ma már adatelemzéssel, matematikai módszerekkel és vizualizációval érzékelhető és láthatóvá is tehető ${ }^{4}$ (1. ábra). 


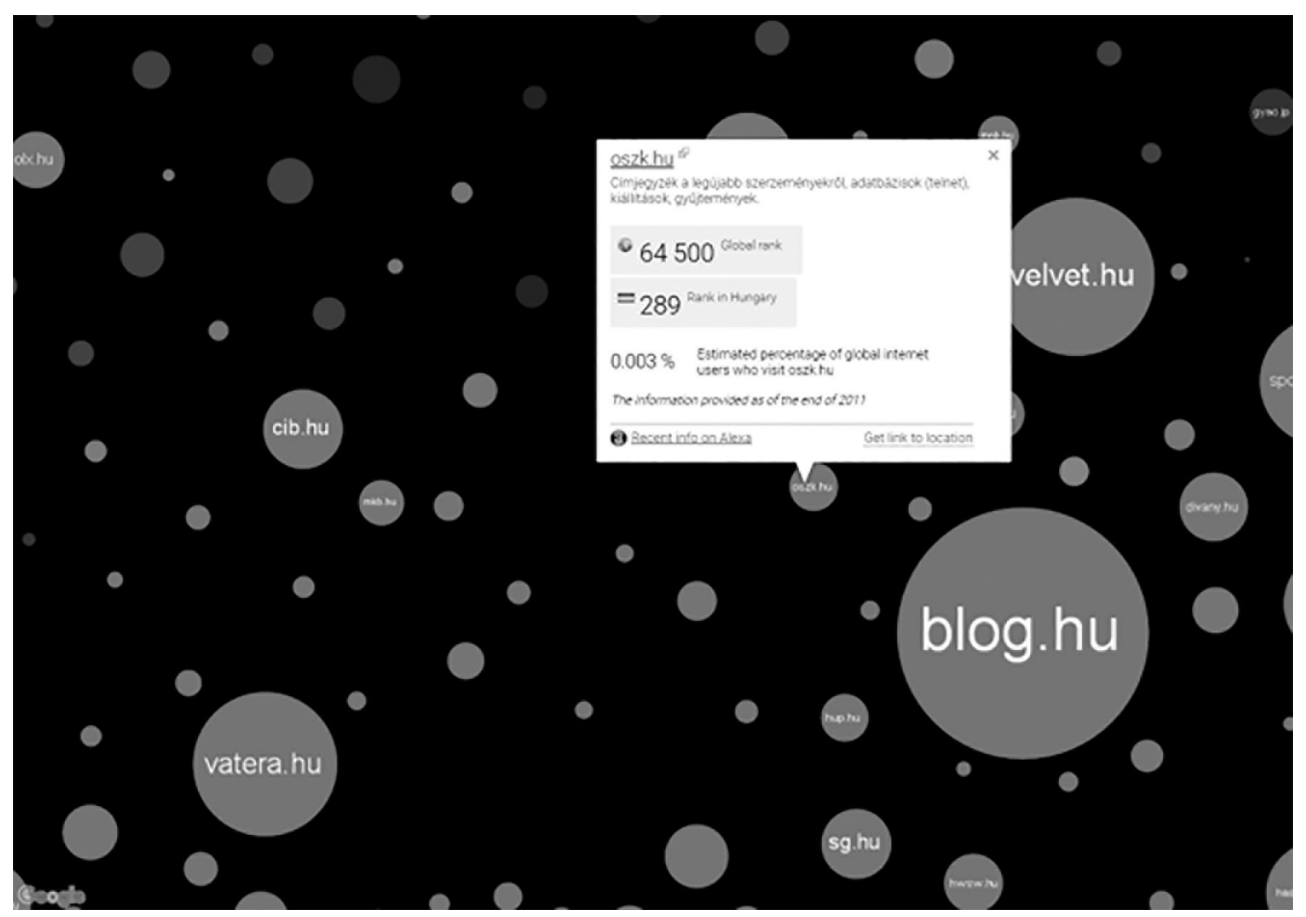

1. ábra: Az Országos Széchényi Könyvtár az internet térképén

A Könyvtár gyűjtési funkciójának eredménye a gyűjtemény. A gyűjtemény alakulása a mindenkori közösségi - általában jogszabályokban megfogalmazott - felhatalmazástól függ. A technológiai környezet változásával és a komplex hálózatok kialakulásával egyre összetettebbé válik a gyűjtési tevékenység határainak kijelölése is.

A nemzeti könyvtárak rendszere a nemzethez kapcsolódó patriotikum fogalmára alapozta gyűjtését. ${ }^{5}$ A patriotikum jelentése is több szempontot tartalmaz (hely, nyelv, identitás és tematika) és figyelembe veszi a politikai határok időbeli változását is. A patriotikum fogalmára építő könyvtári gyűjteményszervezés alapvetően ma is betölti funkcióját, de a komplex hálózatok kialakulásával módosulnak határai is. Hogyan értelmezhető az internet komplex rendszerében a hungarikum könyvtári fogalma? Ha az internet hálózatot térjelenségként értelmezzük, akkor a hálózati csomópontokra értelmezhető a lokalizációs szempont. A .hu domain egyszerre vonatkozhat a lokalizációra, nyelvre és az identitásra. Az egyéb felsőbb szintű domain elemek (.org; .eu; .net, .com stb.) komplexebb hálózati összefüggéseket rejthetnek. A komplex hálózatok előtérbe helyezik a „bibliotheca universalis” vagy „bibliotheca globalis” gondolatát, de már nem Conrad Gessner vagy Borges értelmezésében. 
KÁLDOS JÁNOS

A hagyományos hordozókon lévő analóg kódolású gyűjtemény (analóg gyűjtemény) gyarapításának csatornái nagyrészt változatlanok maradnak a digitális kor jelenleg belátható szakaszában, és a könyvtári állomány növekedése is nagyságrendileg megmarad, de valószínúleg egyre csökken. ${ }^{6}$

A digitális kódolású források növekedése azonban nagy hatással van és lesz a könyvtári gyújtemények alakulására. ${ }^{7}$ Ha tényként elfogadjuk a Moore-törvény - bár lassuló tendenciájú - érvényességét kb. a XXI. század közepéig, ${ }^{8}$ akkor el kell fogadnunk azt is, hogy a könyvtárakba olyan mennyiségü digitális adat kerül az elkövetkezó évtizedekben, amely nagyságrendekkel haladja meg a jelenlegi mennyiséget és átalakítja a gyüjteményben található dokumentumtípusokat is. ${ }^{9}$ A digitális gyüjtemény gyarapodása a következő forrásokból származik: a digitális- vagy e-kötelespéldány (legal deposit), a weben található anyagok szabályozott gyűjtése (webaratás), ${ }^{10}$ a digitalizálás és egyéb nem szabályozható digitális anyagok önkéntes forrásból (voluntary deposit).

A jelenlegi szabályozás (jogszabályi és stratégiai) szerint az OSZK feladatköre bővül a digitalizáláshoz kötődő aggregátori feladatokkal. A magyar könyvtárakból származó digitális másolatok gyarapítják az OSZK digitális gyújteményét, s a nemzeti könyvtár, mint aggregátor egyre inkább „adatközpont” szerepbe kerül. A következő 10-15 évben az OSZK-ban előállított digitális objektumok ${ }^{11}$ (felvételek) száma meghaladhatja az évi tízmilliót. Feltehetőleg a magyar könyvtári rendszerben digitalizált, vagy piaci szereplőkkel digitalizáltatott felvételek száma is legalább ugyanennyi lehet évente. ${ }^{12}$ Jelentősen bővülnek a könyvtárak digitalizáló kapacitásai a Közgyűjteményi Digitalizálási Stratégia ${ }^{13}$ által biztosított és egyéb forrásokból is.

A digitalizálás következményeként a könyvtárak belépnek a könyvtárak számára gyűjtendő dokumentumokat termelő szervezetek, az előállítók (creator, producer) közé. A Könyvtár tehát új funkcióval bővül a digitális kor kezdeti időszakában.

A könyvtárak által végzett digitalizálás elsőrendű célja a hozzáférés növelése. A hozzáférés a végfelhasználó szempontjából értelmezendő. A hozzáférés a könyvtári szolgáltatások segítségével valósul meg. A digitalizálás azonban jelentôsen növeli a könyvtárak digitális gyűjteményét és átalakítja a szolgáltatását is.

\section{Megörzés}

Az adathordozók és az adatok megőrzése növekvő terheket jelent az emlékezet-intézményekben. Az analóg dokumentumok megőrzése is nehéz feladatok elé állítja a könyvtárakat, mivel az idő múlásával a XX. századi adathordozók, s így az adatok egy része egyre erősebben veszélyeztetett állapotba kerül. Az ún. savas papírok, a gyenge minôségú papírra nyomtatott leveles dokumentumok (plakátok, aprónyomtatványok stb.) savtalanítása, restaurálása rendkívül munkaigényes, költséges feladat. A hanghordozók vagy a fényképek és filmek is a nehezen megőrizhető adathordozók közé tartoznak. 
A digitális kód megőrzését biztosító hordozók és az adatokhoz való hozzáférést biztosító eszközök életciklusa - a hosszú távú megőrzés igényéhez képest - rendkívül rövid, gyorsan avulnak a hardverek és szoftverek, beleértve a fájlformátumokat is. A prognosztizálható jelentős nagyságú gyarapodás, a megőrzendő dokumentumok relatíve rövid életciklusa, valamint a hosszú távú megőrzés kötelezettsége egyelőre nehezen megoldható feladat elé állítja a könyvtárakat. A könyvtáraknak érdeke, hogy minél több szabványos formátumú dokumentum kerüljön a gyújteményébe, amelynek biztosított (vagy ma annak látszik) a hosszabb távú elfogadottsága, szabványossága. Ezért támogatják a de jure és de facto standardokat, és saját, illetve partnereik digitalizálását is ebbe az irányba szeretnék terelni különböző ajánlásokkal, szabályzókkal. Ma ezeken a területeken eredményesnek tűnik tevékenységük. Jóval kisebb a befolyásuk azokon a területeken, ahol a piaci dinamika erősebben érvényesül, és a piaci érdekek felülírják a szabályozottság és megőrizhetôség szempontjait. Újabb és újabb formátumok és szolgáltatási formák keletkeznek, amelyek vagy elegendő technikai potenciállal rendelkezve széles körben elterjedve de facto és/vagy de jure szabvánnyá válnak, de aktuális hatásuk elmúltával vagy kiesnek a társadalmi emlékezet rendszereiből, vagy jelentős erőfeszítésekre kényszerítik a megőrzésükért felelős intézményeket.

A könyvtárak digitális gyűjteményeinek hosszú távú megőrző kötelezettsége olyan technikai megoldásokat követel meg, amelyben biztosítható az egyre növekvő mennyiségű anyag állapotának folyamatos ellenőrzése, valamint az elavuló technológiák migrációja, konverziója az aktuálisan optimális megoldásra.

Úgy tűnik, hogy a digitális korszakban átalakul a társadalmi emlékezet megőrzésének felelősségi rendszere is. A könyvtári rendszerek informatikai komplexitása olyan szinteket ér el, amely meghaladja az egyes könyvtárak informatikai lehetőségeit, ezért az infrastruktúrát múködtető és egyéb technológia partnerek között munkamegosztás alakul ki, így a múködtetés és a megőrzés felelőssége is megoszlik. ${ }^{14}$ A munkamegosztás előnyeinek, hátrányainak és hatékonyságának elemzése már elkezdődött, ${ }^{15}$ de a felelősségi rendszer kialakítása és jogszabályokban történő meghatározása még a jövő feladata.

\section{Feldolgozás}

A gyüjtemény feldolgozása biztosítja, hogy az azt alkotó dokumentumok megtalálhatók és hozzáférhetôk legyenek az olvasók, a felhasználók, a társadalom egésze számára. Ez a funkció azonban rendkívül összetett, s nehezen határozhatók meg pontos határai. A könyvtári feldolgozás egy dokumentum tartalmi és formai jellemzőinek szöveges leírását jelenti. Egy kulturális tárgy leírása jellemzőinek megnevezésével történik. Egy dokumentumról készíthetünk minimális és nagyon részletes leírást a tartalmáról és a példány fizikai jellemzőiről. Egy példával illusztrálom a leírás lehetőségeit és a lehetséges szintjeit.

A francia nemzeti könyvtár $(\mathrm{BnF})$ egy XV. századi kódexe a 2. ábrán látható leírással szerepel az 1888-ban megjelent katalógusban. ${ }^{16}$ 
KÁLDOS JÁNOS

\section{Eschyli Prometheus vinctus (3), - VII. ad Thebas (38), - Persæ (73); - præmiltitur Eschyli vita (1). \\ XV s. Copié par le moine Athanase. Pap. 103 fol. (Medic.-Reg. 3330.) P.}

\section{2. ábra: A 2788. tétel a BnF 1888-as katalógusában}

Részletesebb leírása is olvasható a francia nemzeti könyvtár honlapján ${ }^{17}$ és a kódex mikrofilmről készült digitális másolata is elérhető. ${ }^{18}$ Ehhez a szűkszavú bibliográfiai leíráshoz már további adatok is kapcsolódtak: a hozzáférés szabályozására vonatkozó adat (public domain). A francia nemzeti könyvtár restaurátorai ugyanennek a kódexnek a fizikai leírását 47 oldalon végezték el kb. 200 jellemző feltüntetésével (méretek, kötés, anyagok, fúzés). ${ }^{19}$ A könyvtári gyakorlatban több adat is csatlakozhat egy-egy kulturális tárgy leírásához, pl. szerzői jogi státusz adatok (Creative Commons licencek, egyéb korlátozások), érzékeny adatok, technikai adatok, valamint a dokumentum történetére vonatkozó adatok (állapot, kölcsönzés, restaurálás). A megnevezett jellemzők számát általában a rendelkezésre álló erőforrások (idő, pénz, szakértelem stb.) és az elvárt eredmény (cél) határozza meg. A leíró adatsémák, mint a MARC, DC megállapodások és kompromisszumok eredményei. Az újgenerációs könyvtári adatokat kezelő rendszerek 20-40 közé teszik az általában használt elemek számát. ${ }^{20}$ Eddig is illúzió volt egy-egy nagyobb - több millió dokumentumból álló - gyűjtemény homogén feldolgozottságának igénye, a jövőben azonban el kell fogadnunk, és tudatosan kell kezelnünk a könyvtári feldolgozottság különböző - jól definiált - szintjeit. Helyesebb, ha a feldolgozás során az adatok bővítésének különböző állapotait határozzuk meg. Az adatbővítés (preenrichment) az eredeti dokumentum leírását szolgáló tulajdonságok számának növelését és az adattartalom pontosítását jelenti, vagyis megelőzi a szemantikus elemekkel történő adatgazdagítást (enrichment). ${ }^{21}$ Minden leíró elem növeli a potenciális szemantikai kapcsolódások számát. A terjedőfélben lévő könyvtári modellek kibővítik a leírandó és kapcsolatban álló entitások számát (mű, megjelenési forma).

Az entitások azonosítása és az entitások adatainak kezelése az ún. névterekbe kerül. A névterek csak egy újabb állomását jelentik az entitások különböző kapcsolatán alapuló világmodellnek. A névterek jelen voltak az ún. relációs adatkezelő rendszerekben is, de a névterek fejlődési trendjei a globális névterek irányába mutatnak. Néhány globális névtér már ki is alakult (VIAF, GEONAMES, Getty Vocabularies), ${ }^{22}$ de nagyon jól látható a nemzeti névterek kialakulásának trendje is. Az új funkcionális adatmodellek (FRBR-család, IFLA Könyvtári referenciamodell, LRM) ezekre az összetevőkre épülnek és az új katalogizálási szabvány, az RDA is figyelembe veszi ezeket az adatmodelleket. Az OSZK fejlesztési tervei között szerepel a Magyar Nemzeti Névtér rendszer kidolgozása és üzemeltetése. A Magyar Nemzeti Névtér rövid távú terveiben szerepel, hogy kiterjed a személynevekre, földrajzi nevekre, eseményekre. 
A dokumentumokról készített leírások elemi állítások halmazai, amelyek a leírandó dolog és a hozzájuk kapcsolható entitások tulajdonságainak megnevezéseit tartalmazzák, vagyis elemi adatokból épülnek fel, melyek csak kontextusban, kapcsolatrendszerben értelmezhetôk s alakíthatók át információvá.

A digitalizálásból és egyéb forrásokból származó, digitális dokumentumokból épülő gyűjtemény lehetőséget teremt a dokumentumok tartalmának közvetlen szolgáltatására és a szövegekben, illetve a bitmintázatokban való keresésre, valamint az elemi adatok összekapcsolására is. Ennek lépései azonban már a távolabbi jövő felé vezetnek. A további lépések már az adatbányászat, a gépi tanulás és a mesterséges intelligencia világába tartoznak. ${ }^{23} \mathrm{~A}$ feldolgozó könyvtáros és a feldolgozásba bevont közösségek számára a dokumentumokra vonatkozó elemi adatok rögzítése, illetve a szövegébe, mintázatába épülő strukturális és szemantikai elemek (metaadatok) automatikus és/vagy manuális elhelyezésének biztosítása lehet csak a feladat.

Tehát a könyvtári üzem minden folyamatában értékes elemi adatok kerülnek az adatrendszerbe. A könyvtári adat-előállító értéklánc minden résztvevője elemi adatokkal gazdagítja a rendszert. A hálózati térben az elemi adatok között kapcsolatok jöhetnek, jönnek létre. A kapcsolatok kialakítása egyre növekvő mértékben automatizálttá válik, de a mesterséges intelligencia mellett belátható ideig még nem lesz elhanyagolható a humán intelligencia az adatok és kapcsolataik karbantartásában. ${ }^{24}$

A gyűjtemények mint adatok, az elemi könyvtári adatok, az elsődleges források adatai, valamint a gyújteményekbe nem tartozó, de szolgáltatott adatbázisok ${ }^{25}$ adatai áttekinthetetlen, nyomasztóan bonyolult adattömeg képzetét keltik. A könyvtáros és könyvtári szolgáltatások feladata, hogy „megszelídítse” az elszabadult adatokat. A felhasználónak ugyanis azt kell éreznie, hogy az adatok személyesen neki szólnak, az ő bármilyen bonyolult, összetett kérdésére, keresésére is megfelelő választ talál.

\section{Szolgáltatás}

A digitális korban jelentős változások és fókuszváltások történnek a könyvtárak szolgáltatási rendszerében. A Könyvtár szolgáltatási funkciója állandó, de jelentôs differenciálódás megy végbe a könyvtárak között. A szolgáltatások a könyvtár hagyományos tereiben, vagy könyvtárrá alakuló terekben és/vagy az online térben történnek. Léteznek online, szolgáltatás nélküli könyvtárak és léteznek épület nélküli, csak a hálózati térben múködő könyvtárak, de kialakultak a mobil könyvtári szolgáltatások különböző formái is: könyvtárbusz (library bus), könyvtárvonat (library train), vagy nem könyvtári terekben történő szolgáltatási formák, mint például strandkönyvtár (beach library), plázakönyvtár, könyvtári pláza (library plaza, plaza library), pályaudvar könyvtár, könyvtár a kávézóban stb. A könyvtárak elindultak az olvasók felé.

A könyvtárak egy része rendkívül intenzív társadalmi szerepet tölt be már ma is a tudás disszeminációja terén, a digitális írástudás fejlesztésében, s a társadalmi fölzár- 
KÁLDOS JÁNOS

kóztatás, esélyegyenlőség területén. A könyvtárak másik részében, az egyetemeken, az országos és regionális kulturális és szaktudományos központokban a könyvtári épületek komplex kulturális térré alakulnak, ahol a muzeális dokumentumokkal való találkozás néma könyvtári szentélye ugyanúgy megtalálható, mint az egyéni és csoportos tanulás, az önképzés terei és a kiállítóterek vagy konferencia- és koncerttermek. A könyvtárak célközönségük szokásainak figyelembevételével alakítják ki a szokásoknak megfelelő szolgáltatásokat (felhasználói ökoszisztémák). A nemzeti könyvtárak egyszerre töltik be a hagyományos könyvtári funkciókat, a komplex kulturális központ funkcióját, valamint a muzeális intézmény szerepét.

A különböző társadalmi feladatkörű könyvtárak az online térben is differenciált szolgáltatásokkal szolgálják ki olvasóikat, látogatóikat. A lokális elektronikus könyvtári katalógus és kölcsönzés nyilvántartása az alapszolgáltatás része már ma is. Ezek kiegészülnek a lokális-, illetve szakkönyvtárak esetében a szakági igényeknek megfelelő tartalomszolgáltatásokkal, repozitóriumokkal és piaci adatszolgáltatók adatbázisaival. A nemzeti könyvtárak, ha különböző mértékben is, de könyvtári adatkö̈pont ${ }^{26}$ szerepet töltenek be, ami egyrészt a könyvtár gyüjteményét mint adattömeget, másrészt az adatszolgáltatást foglalja magában. A technológiai értelemben vett informatikai „adatközpont” szerepet - jelenleg úgy tűnik - külső szolgáltatók vállalják magukra. A könyvtárak várakozással tekintenek az együttmúködésre, de már jelenleg is fontos elemzések, viták zajlanak a piaci szolgáltatók és a könyvtárak együttmúködéséről. ${ }^{27} \mathrm{~A}$ jelenlegi stratégiai tervek szerint Magyarországon a múzeumok, levéltárak és a könyvtárak technológiai partnerei a Nemzeti Infokommunikációs Szolgáltató Zrt. ${ }^{28}$ NISZ) és a Kormányzati Informatikai Fejlesztési Ügynökség (KIFÜ) lesznek. A társadalmi emlékezet hosszú távú megőrzéséért felelős intézmények és technológiai partnereik felelősségének tisztázása és szabályozása még a jövő feladata.

A digitális adattérben a fogyasztók részéről egyre erősebben fogalmazódik meg az az igény, hogy az adatok minél egyszerűbben, személyes érdeklődésüknek megfelelően legyenen elérhetők. A könyvtári adatközpontként múködő intézmények feladata, hogy az egyre komplexebbé váló gyűjteményüket, adataikat egyszerűen kezelhető eszközökkel tegyék elérhetővé.

\section{Könyvtári Szolgáltatási Platform}

Az Országos Széchényi Könyvtár, a nemzeti könyvtár fejlesztési terveinek segítségével jól szemléltethető a Könyvtár állandósága és változása. Az OSZK célja egy új komplex könyvtári platform megvalósítása.

Az OSZK - a kormány ${ }^{29}$ és a könyvtárak ${ }^{30}$ által is támogatott - fejlesztési terveinek középpontjában egy olyan rendszer megvalósítása áll, amely biztosítja a fentiekben említett változásokhoz szükséges informatikai infrastruktúrát és eszközrendszert. Ennek projektneve Országos Könyvtári Platform (OKP). Üzembe állásának tervezett időpontja 
- a közbeszerzési eljárás elhúzódása miatt - 2019 második felére tehető. A tervezett platform alapelveinek kidolgozása az új könyvtári platform iránti szándékukat kifejező könyvtárakkal együtt készült.

A legmagasabb szintű elvárások a következők: komplex (egyes elemei kapcsolatban állnak egymással); moduláris felépítésű; nyílt (külső rendszerekkel is együttműködik); robusztus (erőteljes, bővíthető infrastruktúra architektúrára épül); dinamikus (folyamatosan rögzíti a rendszer és az adatok változásait); alapvetően nyilt forráskódú; biztosítja az önkéntes csatlakozáson alapuló könyvtári hálózat működését, de biztosítja a csatlakozó könyvárak önállóságát is, valamint szolgáltatás központú szemléletet valósít meg. ${ }^{31}$ A könyvtárak és más közgyüjtemények számára is használhatóvá válik a Magyar Nemzeti Névtér. A könyvtárak számára a következő szolgáltatásokat biztosítják az OSZK új fejlesztései: közös katalógus, integrált ODR és nemzetközi könyvtárközi kölcsönzés, digitalizálási aggregációs rendszer, digitalizálást támogató keretrendszer, hosszú távú digitális megőrzés, adatkonverziós eszközök, központi felhasználó azonosítás, hozzáférés kezelés, módszertani támogatás (e-learning keretrendszer, tananyagok, ajánlások).

\section{Összegzés}

Beléptünk a digitális korba, a big data világába, ami egyszerre óriási lehetőség és megoldandó feladat a könyvtárak számára is. A Könyvtár kettős feladata, hogy megőrizze a társadalmi emlékezet jelentős részét, és hogy biztosítsa a feltételeket a társadalom adatés információszükséglete számára. A Könyvtár tehát a megôrző és információközvetítő (média) rendszerek közé is tartozik. A Könyvtár hely és rendszer, hogy megőrizhetők és hozzáférhetők legyenek az adatok. A Könyvtár alapvető feladatai változatlanok, de változik a hely és a rendszer. Korunkban, a digitális korban megváltozik az adathordozó, a kód, az adatrögzítés, a megőrzés és hozzáférés módja is.

Reméljük, hogy az OSZK fejlesztési terveiben megfogalmazottak és azok megvalósulása segíti a magyar könyvtári hálózat korszerúbb, hatékonyabb múködését, a feladatok világos megosztását, az olvasóink, felhasználóink és látogatóink adatokhoz, információkhoz való korszerú hozzáférését, valamint a könyvtári rendszer információpiaci pozíciójának meghatározását és stabilizálását.

\section{Jegyzetek és irodalom}

1. Az OSZK fejlesztési terveinek megvalósítását a Kormány 1605/2016. (XI. 8.) Korm. határozata (az Országos Széchényi Könyvtár informatikai fejlesztéséhez szükséges források biztosításáról) alapján biztosított közel 10 Mrd-os pénzügyi támogatás, illetve a Kormányzati Informatikai Fejlesztési Ügynökség (KIFÜ) és az OSZK konzorciuma által létrehozott projekt biztosítja. Magának a projektnek a részleteire nem térek ki, csak azokra a szemléleti elemekre, amelyek meghatározzák a fejlesztések irányait. 


\section{KÁLDOS JÁNOS}

2. A könyvtárosok, építészek, fenntartók és döntéshozók az utóbbi években intenzíven foglalkoznak az OSZK új helyre költöztetésével, vagy a jelenlegi épület korszerúsítésével. Ezzel kapcsolatban több kormányrendelet is megjelent és megvalósíthatósági tanulmány is készült.

3. KHANNA, Parag: Konnektográfia. A globális civilizáció jövőjének feltérképezése. Budapest, HVG könyvek, 2017. 52-57. p.

4. Forrás: http://global-internet-map-2017.telegeography.com; http://www.internet-history. info/internet-global-maps.html [2018. július 27.]

5. FERENCZY Endréné: Gyüjteményszervezés. Budapest, Országos Széchényi Könyvtár, 1998. 47-50. p.

6. A növekedésre vonatkozó következő adatok csak nagyságrendi becsléseket szolgálnak. Fremont Rider által megfigyelt szabályszerűség, hogy az amerikai tudományos és szakkönyvtárak gyüjteménye 1831-1938 között tizenhat évenként megduplázódott. - RIDER, Fremont: The scholar and the future of the research library, a problem and its solution. New York, Hadham Press. 1944. 4. p. - Ha elfogadjuk Rider tizenhat éves ciklusát, akkor a magyarországi gyújtemények esetében ennél lényegesen lassabb a növekedés. A könyvtári statisztika szerint 2000 2016 között legföljebb 30-50\%-os a növekedés. Az OSZK esetében is legföljebb 50-70\% között volt a növekedés tizenhat éves ciklusonként az alapítástól kezdődően.

7. A digitális gyűjtemények kialakulása és a digitalizálás a mérés és statisztika módszereiben is jelentős változásokat generálnak.

8. KAKU, Michio: A jövő fizikája. Budapest, Akkord Kiadó, 2012. 53-56. p.

9. Példaként említhetjük, hogy a nyomtatott térképek száma már ma is jól érzékelhetően évrôlévre csökken. A digitális korszak térképei sokkal inkább különböző adathalmazok térképi rétegen megjelenő vizualizációjára épülnek.

10. Az OSZK fejlesztési programjában elkezdődött a több mint egy évtizeddel ezelőtt megálmodott Magyar Internet Archívum pilot projektje (http://mekosztaly.oszk.hu/mia). Próba verziója elérhetô a http://mekosztaly.oszk.hu/mia/demo címen. [2018. június 25.]

11. Digitális objektumnak nevezzük a digitalizálás eredményeként létrejövő elemi digitális egységet (pl. fájlt).

12. Az előbbi számok óvatos becslések. Az OSZK-ban kialakítandó Digitalizáló Központ eszközeinek elméleti teljesítménye ennél jelentősen nagyobb. Az óvatosság részben az eddigi tapasztalatok miatt van, másrészt ilyen tömegű digitalizálás esetében óvatosságra int a logisztikai és feldolgozási folyamatok szervezése és optimalizálása is.

13. Forrás: http://www.kormany.hu/download/9/ac/11000/Közgyújteményi\%20Digitalizlási\%20 Stratégia_2017-2025.pdf [2018. július 27.]

14. A Közgyújteményi Digitalizálási Stratégia a NISZ (Nemzeti Infokommunikációs Szolgáltató) Zrt.-t jelöli meg az archiválásért felelős partnernek. A könyvtári területen - a 1605/2016 (XI. 9.) Korm. határozat az OSZK informatikai fejlesztési tervének végrehajtása eredményeként létrejövő informatikai rendszer „KIFÜ (Kormányzati Informatikai Fejlesztési Ügynökség) által történő folyamatos múködtetésé"-t rendeli el. Egyre több közgyújtemény használja a felhő alapú megoldásokat biztosító rendszereket, mint az Amazon Web Services (AWS - https://aws.amazon.com ; Google Cloud - https://cloud.google.com/ Microsoft Azure - https://azure.microsoft.com).

15. LDCX konferencia (Stanford University, 2018.03.26-28. Forrás: https://library.stanford. edu/projects/ldcx/2018-conference) egyik rendezvényén az AWS szolgáltatásainak hasz- 
nálhatóságát elemezték (AWS Best practices). Köszönöm az adatot Király Péternek, aki nagyszerū beszámolót készített a konferenciáról.

16. Livre inventaire sommaire des manuscrits grecs de la Bibliothèque nationale, Paris. 1888. Parisinus graecus 2788.

17. Title: Grec 2788 Author : ÆSCHYLUS. Auteur du texte Publication date : 1401-1500 Subject : Scholia in tragœdias. Vita Æschyli Subject : Vita Æschyli Type : manuscript Language : greek, ancient Format : Papier. - 103 fol. - Copié par le moine Athanase. - Petit format Description : ÆSCHYLUS. Persæ Description : ÆSCHYLUS. Prometheus vinctus Description : ÆSCHYLUS. Septem ad Thebas Description: (3)Æschyli Prometheus vinctus ; -(38)VII. ad Thebas ; -(73)Persæ ; -(1)præmittitur Æschyli vita Description : Medic.-Reg. 3330. Rights : public domain Identifier : ark:/12148/btv1b10722520m Source : Bibliothèque nationale de France, Département des manuscrits, Grec 2788 Relationship : http://archivesetmanuscrits.bnf.fr/ark:/12148/cc229673 Provenance : Bibliothèque nationale de France Date of online availability : 02/11/2015

18. Forrás: http://gallica.bnf.fr/ark:/12148/btv1b10722520m/f8.image.r=2788 [2018. július 27.]

19. Köszönöm az adatot az OSZK restaurátorainak.

20. Nem állnak rendelkezésünkre az újgenerációs könyvtári platformok fejlesztői háttéradatai, de az EBSCO FOLIO rendszerében 20-40 közötti jellemzővel számolnak. Forrás: https:// wiki.folio.org/pages/viewpage.action?pageId=1414343 [2018. július 27.]

21. Az adatbővítés fogalma nem azonos az üzleti életben és könyvtári gyakorlatban is használt „adatgazdagítás” (data enrichment) fogalmával. - Europeana semantic enrichment framework. Forrás: https://docs.google.com/document/d/1JvjrWMTpMIH7WnuieNq c'T0zpJAXUPo6x4uMBj1pEx0Y/edit\#heading=h.bz78ahr21sjd - MOHAY Anikó: Az adatgazdagítás lehetőségei a kulturális örökségi tartalmakban - az Europeana gyakorlata. Forrás: http://niif.videotorium.hu/hu/recordings/10584/az-adatgazdagitas-lehetosegeia-kulturalis-oroksegi-tartalmakban-az-europeana-gyakorlata. [2018. július 27.]

22. Forrás: http://www.viaf.org; http://www.geonames.org; http://www.getty.edu/research/ tools/vocabularies [2018. július 27.]

23. Ebbe a jövőbe enged bepillantani a Google Talk to Books projektje. Forrás: https://books. google.com/talktobooks. [2018. július 27.]

24. A mesterséges intelligencia és a gépi tanulás fejlődésének sebessége nehezen megjósolható, de az „óvatos jövőkép” szerint a XXI. század közepén már nagy valószínúséggel a célorientált mesterséges intelligencia fogja biztosítani az adatok közötti kapcsolatok bejárását.

25. Ilyenek például a tartalomszolgáltatók (ProQuest, EBSCO, Elsevier stb.) adatbázisai, de ide sorolhatjuk a kulturális intézmények közösen múködtetett adatbázisait.

26. Az adatközpont kifejezést tágabban értelmezem, mint az informatikai szakirodalomban szokás.

27. BREEDING, Marshall: Cloud computing for libraries. = The Tech Set, no. 11. Chicago, ALA TechSource, 2012. - Főként az Amazon (AWS) és a könyvtárak kapcsolatát vizsgálják elsősorban a könyvtárak informatikai hatékonyságának és a szolgáltatás minőségének szempontjából. (Pl. New York City Public Library (NYCPL) Cuts costs, saves time, and scales with AWS. Forrás: https://aws.amazon.com/solutions/case-studies/new-york-publiclibrary; AWS and cloud Best practices: https://library.stanford.edu/projects/ldcx/2018conference/agenda [2018. július 27.] 


\section{KÁLDOS JÁNOS}

28. Forrás: http://www.nisz.hu/hu; http://www.kifu.gov.hu [2018. július 27.]

29. A 1605/2016. (XI. 8.) Korm. határozat az Országos Széchényi Könyvtár informatikai fejlesztéséhez szükséges források biztosításáról - „A Kormány ... egyetért az Országos Széchényi Könyvtár informatikai rendszerének stabilizálása és fejlesztése céljából kidolgozott informatikai fejlesztési tervvel ..."

30. Szándéknyilatkozat egy újgenerációs könyvtári platform szükségességéről, 2016. december 7. „,.. a magyar könyvtáraknak szükséges áttérniük egy hatékony együttműködést biztosító, új generációs, innovatív technológián alapuló közös könyvtári platformra..." Forrás: http://konyvtar.mta.hu/index.php?name=v_1_5_szandeknyilatkozat [2018. július 27.]

31. Előreláthatólag mire nyomdába kerül a tanulmány, addig lezajlik az OKP-re kiírt közbeszerzési eljárás. A további fejleményekről a következő címen értesülhet: http://www.oszk.hu/ okr-projekt.

Káldos János az Országos Széchényi Könyvtár Országos Könyvtári Rendszer Projekt szakmai vezetője. 2014 februárja és augusztusa között megbízott fóigazgatóként vezette a nemzeti könyvtárat. 2014. augusztustól a nemzeti könyvtár általános főigazgató-helyettese. 2016-tól az Országos Könyvtári Rendszer Projekt szakmai vezetője. 